\title{
Barriers to Mathematics Teachers' Use of Their Knowledge of Students' Learning Styles in Mathematics Teaching: A Case of Secondary Schools in Zimbabwe
}

\author{
Edmore Mangwende ${ }^{1^{*}}$, Aneshkumar Maharaj ${ }^{2}$ \\ ${ }^{1}$ Vengere High School, ZIMBABWE \\ 2 University of KwaZulu-Natal, SOUTH AFRICA
}

Received 24 March 2019 - Revised 22 April 2019 • Accepted 6 May 2019

\begin{abstract}
This qualitative research study explored barriers that impinged on teachers' use of their knowledge of students' learning styles in teaching mathematics. It was a case study of three secondary schools in the Makoni District of Manicaland Province in Zimbabwe. Participants were fifteen mathematics teachers. Results revealed that the barriers were related to the teachers, the students, the curriculum and the socio-economic status of the schools. Collaborative teaching, formation of mathematics clubs, mobilisation of resources, use of excursions and in-servicing of teachers were recommended as ways of reducing the effects of the barriers.
\end{abstract}

Keywords: barriers, learning styles, mathematics teaching, secondary school, students' learning styles, teaching styles

\section{INTRODUCTION}

Numerous studies have shown that mismatches between teachers' teaching styles and their students' learning styles result in ineffective learning (Peacock, 2001; Reid, 1987; Zeeb, 2004). In our opinion, mathematics teachers struggle to make their students grasp concepts because of mismatches between their teaching styles and their students' learning styles. We therefore suggest that in addition to subject content knowledge, a mathematics teacher should possess knowledge of his or her students' learning styles. The knowledge enables the teacher to plan for instruction that suits all students in his or her class. Surprisingly, reviewed literature revealed that some mathematics teachers disregard their students' learning styles when planning learning instruction (Peacock 2001; Zeeb, 2004). In a study done at a Hong Kong University, Peacock found some mismatches between mathematics teachers' teaching styles and their students' learning styles. According to Peacock, the mathematics teachers' plans of teaching instruction were not based on their students' learning styles. These findings were confirmed by Zeeb. Zeeb studied how junior high school mathematics teachers taught their students. The study revealed serious mismatches between the teachers' teaching styles and their students' learning styles.

According to Nziramasanga, Malaba, Kachingwe and Gerbecks (1999), mathematics teachers in Zimbabwe used traditional teaching strategies that did not match the needs of their students. Nziramasanga et al. found that demonstrations, question and answer sessions, lectures and use of exercises from textbooks were the most common strategies used by the teachers. In another study carried out in Makoni District of Manicaland Province in Zimbabwe, it was found that not all mathematics learners benefited from their teachers' teaching strategies due to mismatches between teachers' teaching strategies and students' learning styles (Mangwende \& Maharaj, 2018).

However, due to lack of research, it remained unknown whether there were barriers that made it difficult for the mathematics teachers to effectively use their knowledge of their students' learning styles in planning and delivering lessons. The current study was done in order to cover the knowledge gap that existed by exploring barriers to mathematics teachers' use of their knowledge of students' learning styles in mathematics teaching. The study was based on the assumption that some barriers existed and these made it difficult for mathematics teachers to fully utilize their knowledge of students' learning styles in planning and delivering mathematics lessons.

(C) 2020 by the authors; licensee Modestum Ltd., UK. This article is an open access article distributed under the terms and conditions of the Creative Commons Attribution License (http://creativecommons.org/licenses/by/4.0/). \mangwendeeddy@gmail.com (*Correspondence) \maharaja32@ukzn.ac.za 


\section{Contribution of this paper to the literature}

- The paper presents to the world the barriers that impinge on the mathematics teachers' effective utilisation of their knowledge of students' learning styles in teaching mathematics.

- The findings revealed that the barriers were related to the teachers, the students, the curriculum and the socio-economic status of the schools.

- The barriers could be overcome by in-servicing teachers, mobilisation of resources, collaborative teaching and integration of mathematics with other learning areas.

\section{RESEARCH QUESTION}

The study was guided by the following research question: What are the barriers that impinge on secondary school mathematics teachers' use of their knowledge of students' learning styles when teaching mathematics?

\section{LITERATURE REVIEW}

This section focuses on: The concept of learning styles; Learning style models; Concept of differentiated mathematics teaching; Barriers to mathematics teaching.

\section{The Concept of Learning Styles}

Patel and Singh (2014) define learning styles as the ways a learner concentrates on, processes, internalises and remembers new academic information. Haar, Hall, Schoepp and Smith (2002) refer to learning styles as individual differences in perceiving, processing and communicating information. In simple terms, learning styles are unique ways a learner prefers learning. Learning styles explain how a learner perceives learnt concepts and how he or she makes scholarly decisions. They also explain how the learner interacts with the learning environment. The learning environment comprises among others the learner's peers, the teacher and the society.

According to Perini, Silver and Strong (1997), the learning style theory began with a theorist called Carl Jung in 1972. Jung noted some differences in learners' perceptions, interaction and decision making skills. Jung's work challenged a number of researchers who then developed interest in understanding specific differences in human learning. As a result of numerous studies on how human beings learn, different learning style models were developed.

\section{Learning Style Models}

In this subsection, the focus is on learning style models developed by the following theorists: Kolb (1984); Honey and Mumford (1982); Perini, Silver and Strong (2000).

\section{Kolb's Experiential Model}

Kolb (1984) proposed an experiential model of learning styles. As a cognitive theorist, Kolb thought students' experiences, which are a result of the students' interaction with the environment, determine the students' learning styles. According to Kolb, four classes of students based on their learning styles exist. The classes are divergers, assimilators, convergers and accommodators. Divergers are imaginative and creative. They can easily work with other students in groups. Assimilators are able to work with abstract ideas. They are good at creating theoretical models and they normally use inductive reasoning when solving mathematical problems. Convergers prefer performing technical tasks. They dislike dealing with social issues. In solving problems they normally use deductive reasoning. Accommodators are risk takers. They enjoy learning by doing and are able to solve practical problems intuitively.

According to Kolb, all learners despite their learning styles pass through four stages of a learning cycle. It is the duty of the teacher to assist the students to effectively pass through all the four stages. For that reason, the teachers need to know the learning styles of all their students. Figure $\mathbf{1}$ shows the four stages of the learning cycle as suggested by Kolb. 


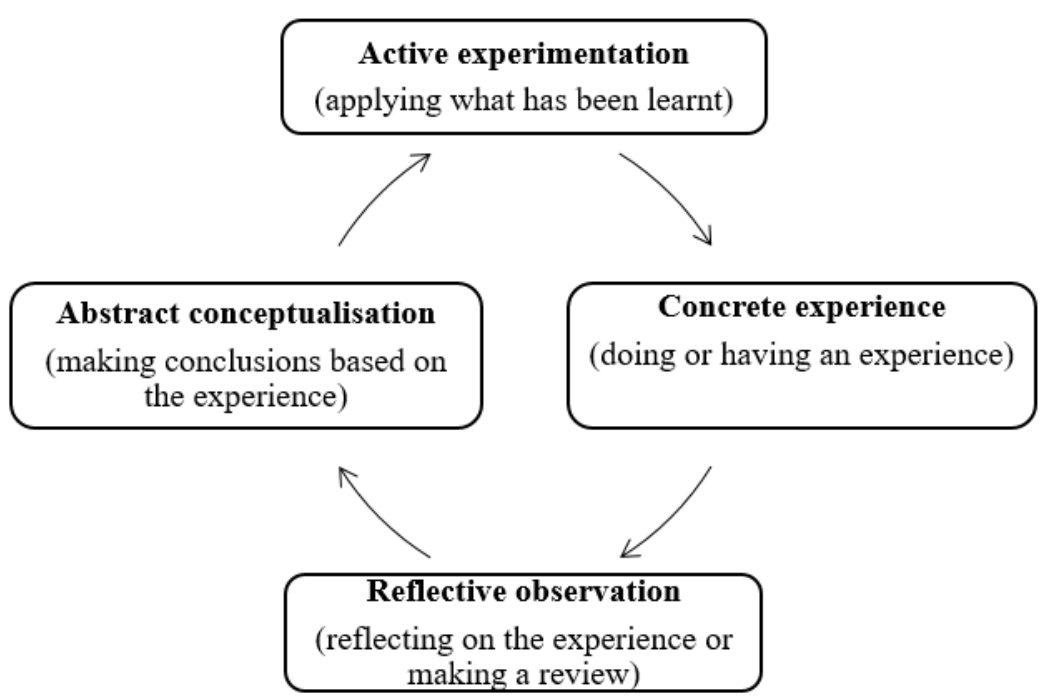

Figure 1. Four learning stages by Kolb (adopted from McLeod, 2017)

In order to illustrate Kolb's learning cycle, let us consider a student learning to calculate perimeter of a circle. In the concrete experience stage, the student cuts small pieces of wire of different sizes. The student measures and records the lengths of the pieces of wire. The pieces of wire are bent into circular shapes to make rings. The student measures and records the diameter of each ring. At the reflective observation stage, the student divides the lengths of the pieces of wire by the corresponding diameters of the rings made by the pieces of wire. The student observes that a common result comes out when the length of wire is divided by the diameter of the ring. The observation leads to a stage where the student concludes that length of the piece of wire divided by the diameter of the ring gives approximately 3.1428 (value of $\pi$ ). This stage is the abstract conceptualisation stage. By observing patterns, the student develops the formula for perimeter of a circle, $\mathrm{P}=\pi \mathrm{d}$, where $\mathrm{P}$ is the length of the piece of wire or the perimeter of the ring and $\mathrm{d}$ is the diameter of the ring (circle). The student applies the formula to real life problems. At this stage, the student reaches the active experimentation stage. In applying the formula, the student meets new challenges and gets new experience with concepts of higher order. For example, the student may want to find the length of an arc. He or she cuts a piece of the wire that forms the perimeter of the circle, measures and records the length of the piece of wire. The student measures and records the angle that subtends the part of the circumference removed. This takes the student back to the concrete experience stage. The cycle continues as the student develops a formula for length of an arc of a circle by observing the relationship among the perimeter of the circle, the length of the arc and the angle that subtends the arc. However, for a student to smoothly pass through the stages of the learning cycle, he or she requires assistance from a teacher.

\section{Honey and Mumford Model}

Honey and Mumford (1982) also developed a learning style model. Their classification of learners is shown in Table 1. 
Table 1. Learning style model by Honey and Mumford

\begin{tabular}{lll}
\hline Class of learners & Description & Learning activities preferred \\
\hline Activists & - learn by doing & - problem solving \\
& - always want to experiment & - group discussion \\
& - open to group discussions & - puzzles \\
& & - competitions \\
\hline Pragmatists & - always want to know how concepts learnt work in real life & - Applying learnt concepts to real life situations \\
& - dislike abstract concepts & - problem solving \\
& - do not enjoy games & - discussions \\
\hline Theorists & - try out ideas and theories & \\
& - need role models & - following role models \\
& - seek to develop new information into logical theories & - gathering statistics \\
& & - using quotes \\
\hline Reflectors & - observe before taking action & - seeking background information \\
& - are not risk takers & - paired discussions \\
& - take time to get to a conclusion & - completing self-analysis questionnaires \\
& & - observing activities \\
& & - getting feedback from others \\
& & - coaching others \\
& & - interviewing others \\
\hline
\end{tabular}

\section{Perini, Silver and Strong Model}

Another learning style model was developed by Perini, Silver and Strong (2000). Perini et al. classified mathematics learners into four classes. The classes are 'mastery maths learners', 'interpersonal maths learners', 'understanding maths learners' and 'self-expressive maths learners'. Mastery maths learners enjoy learning mathematics through application of formulae, rules, procedures and algorithms. They face difficulties when solving non routine problems. To them a good teacher is one who coaches them to solve mathematical problems. They prefer a teacher who demonstrates to them. Interpersonal maths learners learn better when they work with others in groups. They enjoy solving problems with real life applications. Understanding maths learners always seek to prove and explain why and how concepts learnt work practically. They thrive to find mathematical patterns or trends in the problems they solve. Self-expressive maths learners look for different alternatives to solve mathematical problems. They possess skills necessary for solving non-routine problems. They sometimes use imaginations when solving mathematical problems.

The classes of maths learners and the learning activities preferred by the learners are summarised in Table 2.

Although learning style theorists interpret personality in different ways, they agree in some way (Perini, Silver \& Strong, 1997). They all focus on how individuals absorb, evaluate and think about new information. Their main emphasis is on how individuals think and feel about new concepts. The three models reviewed above agree that learners approach learning in different ways. For the purpose of this study, the researchers adopted the model developed by Perini, Silver and Strong (2000). The researchers realised that the model was the most recent of the three models reviewed and it could be applied directly to mathematics learning. 
Table 2. Learning style model by Perini, Silver and Strong (adopted from Mangwende \& Maharaj, 2018)

\begin{tabular}{|c|c|c|}
\hline Class of learners & Description & Preferred learning activities \\
\hline $\begin{array}{l}\text { Mastery maths } \\
\text { learners }\end{array}$ & $\begin{array}{l}\text { - Learn in a step by step manner } \\
\text { - Enjoy solving problems by following algorithms, theorems and } \\
\text { formulae } \\
\text { - Have difficulties in solving non-routine problems } \\
\text { - Prefer teachers who coach them } \\
\text { - Judge learning by clarity and practicality of the concepts learnt } \\
\text { - Possess skills to use numbers in computing, describing and } \\
\text { documenting reports } \\
\text { - Students can be good accountants, bookkeepers or statisticians }\end{array}$ & $\begin{array}{l}\text { - Application of algorithms, } \\
\text { formulae and theorems } \\
\text { - Computing } \\
\text { - Producing mathematical reports }\end{array}$ \\
\hline $\begin{array}{l}\text { Interpersonal } \\
\text { maths learners }\end{array}$ & $\begin{array}{l}\text { - Learn through dialogue and collaboration } \\
\text { - Are interested in how mathematics concepts help in real life } \\
\text { - Have difficulties in solving problems as individuals } \\
\text { - Do not like solving problems that do not have real life application } \\
\text { - Want teachers who appreciate their successes and struggles } \\
\text { - Judge mathematics learning by its potential to help people } \\
\text { - Possess skills to apply mathematics in personal and daily life } \\
\text { - Students can be good home makers }\end{array}$ & $\begin{array}{l}\text { - Group discussions } \\
\text { - Applying mathematical concepts } \\
\text { in solving real life problems }\end{array}$ \\
\hline $\begin{array}{l}\text { Understanding } \\
\text { maths learners }\end{array}$ & $\begin{array}{l}\text { - Seek to understand why mathematics concepts work } \\
\text { - Like problems that allow them to prove and explain reasons for } \\
\text { taking certain decisions } \\
\text { - Seek patterns in mathematical concepts } \\
\text { - Have difficulties in working with others in solving problems } \\
\text { - Judge learning by use of evidence and logic } \\
\text { - Possess skills to use mathematical concepts in establishing proofs } \\
\text { and constructing scientific arguments } \\
\text { - Students can be good scientists, quantitative problem solvers or } \\
\text { logicians }\end{array}$ & $\begin{array}{l}\text { - Proving why concepts work in } \\
\text { real life } \\
\text { - Individual work } \\
\text { - Identifying mathematical patterns } \\
\text { - Constructing scientific arguments }\end{array}$ \\
\hline $\begin{array}{l}\text { Self-expressive } \\
\text { maths learners }\end{array}$ & $\begin{array}{l}\text { - Use imaginations to solve mathematics tasks } \\
\text { - Enjoy solving non-routine problems } \\
\text { - Generate possible solutions by exploring alternatives } \\
\text { - Judge learning by originality of the concepts learnt } \\
\text { - Possess abilities to use logic and develop models } \\
\text { - Students can be good designers, engineers or qualitative problem } \\
\text { solvers }\end{array}$ & $\begin{array}{l}\text { - Solving non-routine problems } \\
\text { - Solving project-like problems } \\
\text { - Developing mathematical models } \\
\text { - Designing }\end{array}$ \\
\hline
\end{tabular}

\section{The Concept of Differentiated Mathematics Teaching}

In view of the fact that learners have different learning styles, some scholars suggest that mathematics teachers adopt the concept of differentiated teaching (Tomlinson, 2001; Weselby, 2014). According to Weselby, differentiated teaching simply means teaching the same content to different students using a variety of teaching strategies. It involves modifying the content (what to teach), the process (how to teach it) and the product (how the learners demonstrate their learning) in order to suit the needs of the individual learners (Carlson, 2018). According to Allan and Tomlinson (2000), the teacher needs to create a learning environment that invites the attention of all learners. This can be achieved by being innovative and by using a variety of learner-centred teaching strategies that suit the learning styles of the students. Learner-centred teaching strategies include use of mathematics learning centres, group discussions, information and communication technology (ICT) systems and peer teaching.

\section{Barriers to Mathematics Teaching}

Kaniz (2015) defined barriers as factors that inhibit or prevent people from participating in activities. For this study, barriers refer to rules, policies or any other things or events that hindered or prevented mathematics teachers from using their knowledge of students' learning styles to the best advantage of their students. The literature reviewed exposed lack of research on barriers to mathematics teaching related to the use of teachers' knowledge of students' learning styles. However, the literature revealed that mathematics teaching in general had numerous barriers. Kaniz carried out a study in Bangladesh which uncovered that mathematics teachers were facing a number of barriers. The barriers were classified under three categories. The categories were societal, pedagogical and systematic barriers. Societal barriers included negative perceptions about mathematics as a learning area that were held by members of the society (including the students and the teachers). The society viewed mathematics as a subject in which boys perform better than girls. Pedagogical barriers were those that were related to teachers' teaching 


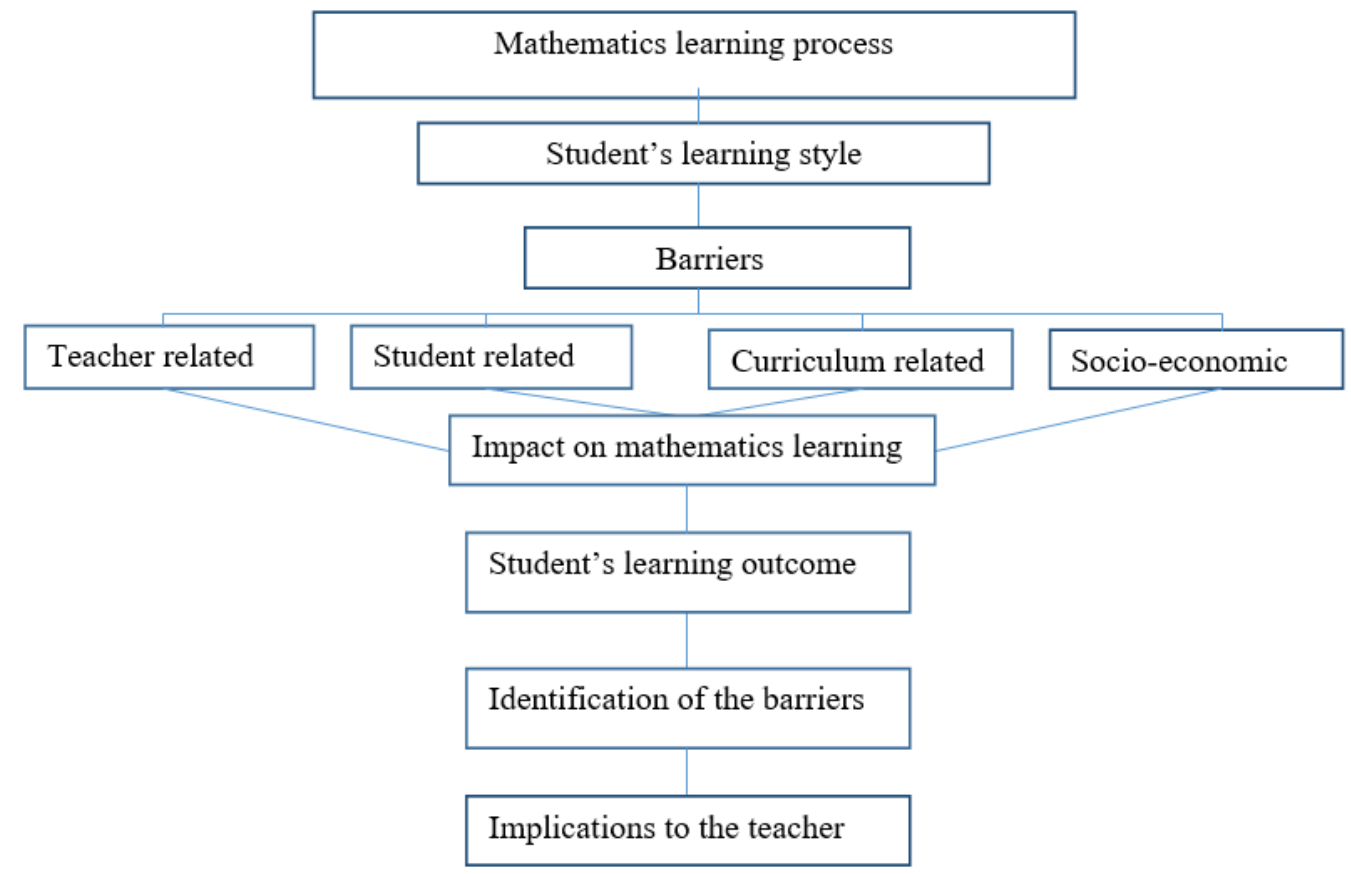

Figure 2. Conceptual framework (adopted from Kaniz, 2015)

strategies. Among these was the use of severe punishment for failing to solve mathematical problems. According to the study by Kaniz, the use of punishment resulted in students developing negative attitude towards mathematics learning. Systematic barriers included lack of suitable resources like textbooks and other mathematical instruments.

In another study, Crystal (2012) reported on barriers that affected the teaching of mathematics and science in Michigan. The results of the study indicated that the most prevalent barriers were lack of motivation on the part of the students and lack of parental support to education.

In a study carried out in Mabasa South District in Kenya, Oisebe (2012) found that lack of in-service courses for teachers and low expectation of mathematics performance on students by their teachers were common barriers to mathematics teaching. The mathematics teachers in Kenya did not expect some of their students to excel in mathematics. The teachers' attitude contributed to low performance by the students as they got little support from the teachers.

Marban and Mulenga (2019) observed that mathematics teachers' attitude towards use of information and communication technology (ICT) was a barrier to mathematics teaching. Marban and Mulenga studied the relationship between pre-service teachers' teaching styles and the teachers' attitude towards use of ICT. The results of the study revealed that the teachers had a negative attitude towards use of ICT. The attitude impacted negatively on mathematics teaching. Studies have shown that integration of mathematics teaching and use of ICT creates a learner friendly environment that facilitates differentiated teaching (Allan \&Tomlinson, 2000).

\section{CONCEPTUAL FRAMEWORK}

The current study adopted a conceptual framework drawn from a theory by Kaniz (2015). The framework is shown in Figure 2.

\section{METHODOLOGY}

This section gives a description of the research design, research participants, ethical considerations and research instruments. It also explains how the data used in the study were collected and analysed.

\section{Research Design}

The study followed a qualitative paradigm. It was an exploratory case study of secondary schools in Makoni District of Manicaland Province in Zimbabwe. According to Zaidah (2007) an exploratory case study seeks to explore a phenomenon of interest in a chosen field. For the current study, a case study enabled the researchers to 
Table 3. Participants' demographic information $(n=15)$

\begin{tabular}{|c|c|c|c|c|c|c|}
\hline & \multicolumn{3}{|c|}{ Teaching experience in full years } & \multicolumn{3}{|c|}{ Highest professional qualifications } \\
\hline & Less than 5 & Between 5 and 10 & More than 10 & Diploma in Education & Bachelor's degree & Master's degree \\
\hline Males & 1 & 3 & 3 & 2 & 3 & 2 \\
\hline Females & 1 & 1 & 6 & 4 & 4 & 0 \\
\hline Total & 2 & 4 & 9 & 6 & 7 & 2 \\
\hline
\end{tabular}

get in-depth and detailed understanding of the barriers affecting the effective utilization of the teachers' knowledge of students' learning styles in mathematics teaching. A case study was suitable since a small geographical area and a small number of teachers were used in the study.

\section{Research Participants}

Fifteen secondary school mathematics teachers participated in the study. These were selected from three secondary schools in the Makoni District of Manicaland Province in Zimbabwe. The three schools were selected using stratified random sampling method. Using stratified random sampling method in selecting schools helped the researchers to ensure that schools under different responsible authorities were selected for the study. The responsible authorities were: The Government, local councils and private owners (including churches).For the purpose of applying stratified sampling method, the responsible authorities were treated as clusters. A school from each of the three clusters was selected at random. All the mathematics teachers at the selected schools participated in the study. The demographic information of the mathematics teachers is shown in Table 3.

\section{Research Instruments}

Data used in this study were obtained through structured face to face interviews and through observation. An interview guide and an observation checklist were prepared in advance. The interview guide had closed and openended questions. It had five sections. The first section sought data on the participants teaching experience and professional qualifications. In the second section, the interviewers required the interviewees to state and explain barriers that were related to teachers' personal attributes and pedagogical skills. The third, fourth and fifth sections required the teachers to state and briefly explain giving examples barriers that were related to the students, the curriculum and the socio-economic status of the school respectively. In the sixth section, the mathematics teachers were asked to give any other barriers that could not be classified under the given categories. Structured face to face interviews provided an opportunity for the interviewer to clarify questions that were not clear to some of the interviewees. The use of interviews also made it possible for the interviewer to make sure that interviewees responded to all questions.

Observation was also used as a data collection instrument. Fifteen lessons taught by the participating teachers were observed. During the lessons, the researchers took notes on observable barriers to the teachers' effective use of their knowledge of students' learning styles.

\section{Validity and Reliability}

In order to ensure credibility of the findings, triangulation was done in two ways. Data obtained through face to face interviews were triangulated with data obtained through observation. This was a form of research instruments triangulation. In addition to instrument triangulation, researcher triangulation was also done. All interview sessions were recorded on audio tapes. The data on the audio tapes were analysed by two investigators separately. The results were then discussed and a consensus was reached before producing a draft report.

Confirmability of the findings was ensured by use of the participants' own words in data analysis. This was done as a way of reducing researcher bias and maintaining objectivity and neutrality of the findings.

Before collecting data from the participants, the interview guide and the observation checklist were given to two experts in the field of qualitative research for scrutiny. Ambiguous questions were identified on the interview guide and these were corrected accordingly.

\section{Ethical Issues}

Permission to carry out the study was sought from the office of the Permanent Secretary of the Ministry of Primary and Secondary Education and from the Heads of the chosen schools. The mathematics teachers who participated in the study were informed of the purpose of the study. They were also informed of their rights in the study. All the fifteen teachers agreed to participate and were asked to fill in a consent form. Venues, dates and time 
Table 4. Teacher related barriers and how they affected the teachers' use of their knowledge of students' learning styles in mathematics teaching

\begin{tabular}{ll}
\hline Teacher related barriers & Effect of the barriers \\
advancement & $\begin{array}{l}\text { The teachers could not keep pace with the dynamic world of mathematics } \\
\text { teaching and they failed to use strategies that suited the learning styles of the } \\
\text { modern students. }\end{array}$ \\
\hline Lack of subject content knowledge & $\begin{array}{l}\text { Over reliance on textbooks led to failure by the teachers to match students' } \\
\text { learning styles and learning activities. }\end{array}$ \\
\hline Teachers' own learning styles & $\begin{array}{l}\text { Teachers taught mathematics concepts in ways they preferred being taught and } \\
\text { they disregarded their students' learning styles. }\end{array}$ \\
\hline Failure to integrate mathematics with other & $\begin{array}{l}\text { Students who enjoyed applying mathematical concepts to real life situations were } \\
\text { disadvantaged. Mathematics was taught in isolation and it became too abstract } \\
\text { learning areas and failure to link topics } \\
\text { logically }\end{array}$ \\
\hline $\begin{array}{l}\text { Unfavourable interpersonal relationship students. } \\
\text { between teachers and students }\end{array}$ & $\begin{array}{l}\text { Teachers who distanced themselves from their students faced challenges in } \\
\text { realising their students' learning styles. }\end{array}$ \\
\hline Failure to identify students' learning styles & $\begin{array}{l}\text { Resulted in mismatches between teacher's teaching styles and students' learning } \\
\text { styles. }\end{array}$ \\
\hline Inexperience and lack of exposure & $\begin{array}{l}\text { Limited the teachers' abilities to use a variety of teaching styles to suit the } \\
\text { different learning styles of the students. }\end{array}$ \\
\hline Lack of commitment to work and negative & $\begin{array}{l}\text { The teachers lacked motivation to teach their students according to their } \\
\text { different learning styles. }\end{array}$ \\
\hline attitude towards work & $\begin{array}{l}\text { No cross pollination of ideas among the teachers on how to effectively assist the } \\
\text { students. }\end{array}$ \\
\hline
\end{tabular}

of interviews and lesson observations were agreed between the researchers and the mathematics teachers. This was done so as to avoid disturbing the normal daily work of the teachers.

\section{Data Collection and Analysis}

The data were collected and analysed using qualitative content analysis method as outlined by Bengtsson (2016). According to Bengtsson, content analysis method entails presenting data in words and themes. It involves an analysis of the actual words said by the participants and an analysis of the underlying meaning of the words.

As stated before, data used in the current study were collected through structured face to face interviews and through observations. An interview session took approximately thirty minutes. The sessions were recorded on audio tapes. One lesson per teacher was observed.

Qualitative data analysis tool called ATLAS.ti was used to arrange, assemble, code and manage the data obtained from the mathematics teachers. The data obtained were coded and themes were developed. The barriers obtained were classified under teacher related, student related, curriculum related and socio- economic. The results were presented in table form. Some of the statements shared by the teachers during face to face interviews were quoted verbatim in order to support the data analysis.

\section{RESULTS}

These were noted under the following categories: teacher related barriers; student related barriers; socioeconomic barriers; curriculum related barriers.

\section{Teacher related Barriers}

The data obtained exposed a number of teacher related barriers. Table 4 shows the teacher related barriers and how they affected the effective use of the teachers' knowledge of students' learning styles in mathematics teaching as expressed by the mathematics teachers.

The following were some of the statements said by some of the mathematics teachers:

\footnotetext{
"I trained as a teacher three decades ago. I am three decades behind modern techniques and strategies in mathematics teaching. I need to update myself in order to suit the learning styles of today's students." (Mr A, pers.com).

"Despite being aware of the students' learning styles, my own learning style determines my style of teaching."(Ms B, pers.com).
} 
"Not all mathematics teachers are able to identify their students' learning styles. It takes some form of experience in working with students. Workshops and mathematics panels are important in assisting us."(Ms C, pers.com).

"We sometimes fail to integrate mathematics with other learning areas. Integrating mathematics with other subjects assists students of different learning styles. For instance, if we integrate mathematics with Technical Graphics we assist students who learn better by manipulating objects." $(\mathrm{Mr} \mathrm{D}$, pers.com).

During five $(33.33 \%)$ of the lessons observed, students were not given opportunities to freely interact with the teachers. Lecture method was used by the teachers. The teachers demonstrated on the chalkboard. Students were asked to follow the teachers' demonstrations. The environment that existed in the classrooms indicated an existence of unfavourable relationship between the teachers and the students.

\title{
Students related Barriers
}

According to the mathematics teachers, certain behaviours by their students made it difficult for them to effectively utilise their knowledge of students' learning styles in teaching mathematics. Such behaviours include: absenteeism, indiscipline, negative self-esteem, negative attitude towards mathematics, lack of concentration and lack of continuous practice. The teachers felt that their efforts in utilising their knowledge of students' learning styles in teaching mathematics were seriously affected by unfavourable behaviours by the students. Two of the teachers shared the following sentiments:
"As a teacher I may be enthusiastic to teach the students in the rightful way, but sometimes I will be put off by the way the students behave. Some of them are not serious with their school work. They learn mathematics at school and it ends there, no further practice at home. If you give them homework they do not do it wholeheartedly."(Ms H, pers.com).
"It disappoints to plan for students who dislike the subject. Some are good in mathematics but they are not disciplined or they lack positive self-esteem." (Mr K, pers.com).

One of the teachers $(6.67 \%)$ thought bad teacher-students relationship was also a barrier to effective utilisation of the teachers' knowledge of students' learning styles in mathematics teaching. According to the teacher, students' attitude towards their teachers determined the relationship between the teachers and the students. The teacher said:

\begin{abstract}
"Relationship between the teacher and the students needs to be positive. It facilitates effective students' assessment by the teacher. The assessment enables the teacher to employ suitable teaching strategies that suit the students' learning styles. However a suitable teacher-student relationship will not exist if the student holds a negative attitude towards the teacher or when the teacher holds a negative attitude towards the student." (Mr T, pres.com).
\end{abstract}

\section{Socio-economic Barriers}

Apart from teacher related and student related barriers, the mathematics teachers felt that some of the barriers were related to the socio- economic status of the schools and that of the communities surrounding the schools. Table 5 shows the socio-economic barriers reported by the teachers.

Eight mathematics teachers $(53.33 \%)$, who taught at rural schools, attributed their failure to teach students according to their learning styles to lack of resources. According to the teachers, resources that suited the learning styles of the students were required. Data obtained through observation confirmed that the teachers were working with very little resources. In eight (53.33\%) of the lessons observed, the teachers did not use any teaching aids other than the chalkboard. Individual work given to the students was written on the chalkboard. The average textbookstudents ratio for the lessons observed was 1:6. The researchers also noted that in all the lessons observed, the teachers did not use information and communication technology systems (ICT). One of the teachers said:

$$
\begin{aligned}
& \text { "Shortage of resources makes it difficult for us to fully utilise our knowledge of our students' learning } \\
& \text { styles as expected."(Mr E, pers.com). }
\end{aligned}
$$

One of the teachers blamed school administration for poor timetabling. The teacher said:

\footnotetext{
"Most mathematics lessons are in the morning. The lessons are normally disturbed by other morning activities done at school. Instead of six lessons per week per class we may end up with five or four lessons per week per class. It affects time for students' interaction."( $\mathrm{Mr} \mathrm{G}$, pers.com).
} 
Table 5. Socio-economic barriers and how they affected the teachers' use of students' learning styles in mathematics teaching Socio-economic barriers Effect of the barriers

\begin{tabular}{|c|c|}
\hline $\begin{array}{l}\text { Shortage of learning } \\
\text { resources }\end{array}$ & $\begin{array}{l}\text { Resources were not available in required qualities and quantities. The resources included textbooks, } \\
\text { mathematical instruments, stationery, and ICT systems. }\end{array}$ \\
\hline $\begin{array}{l}\text { Learners' financial } \\
\text { backgrounds }\end{array}$ & $\begin{array}{l}\text { Students failed to get extra resources to use for further practice at home especially in doing } \\
\text { homework. }\end{array}$ \\
\hline Poor timetabling & $\begin{array}{l}\text { Morning school activities affected time allocated for mathematics learning. Church schools had } \\
\text { devotion sessions in the morning which affected morning mathematics lessons by reducing time for } \\
\text { interaction between the teachers and the students. Time for students to do their learning activities } \\
\text { was reduced. }\end{array}$ \\
\hline $\begin{array}{l}\text { Unfavourable school } \\
\text { policies }\end{array}$ & $\begin{array}{l}\text { Mathematics teachers were assigned core curricula duties like attending sporting activities resulting } \\
\text { in them having little time with their students. }\end{array}$ \\
\hline $\begin{array}{l}\text { Large class sizes } \\
\text { and too many lessons per } \\
\text { week }\end{array}$ & $\begin{array}{l}\text { Teachers were overloaded. They did not have enough time to assess each and every student so that } \\
\text { instruction could be planned to suit the learning styles of the students. }\end{array}$ \\
\hline $\begin{array}{l}\text { Negative perceptions of } \\
\text { mathematics as a } \\
\text { learning area }\end{array}$ & $\begin{array}{l}\text { Little effort was exerted by students with negative perceptions. Parents with negative perceptions of } \\
\text { mathematics as a learning area did not give material or moral support to their children. }\end{array}$ \\
\hline
\end{tabular}

The mathematics teachers also pointed out that some school policies affected the effective use of their knowledge of students' learning styles. For instance, it was a policy at all the studied schools that teachers participated in extra curriculum activities like sporting. The teachers felt that they were robbed of valuable time to effectively use methods that assist students with different learning styles. A teacher at one of the schools complained as follows:

\title{
"Too many programmes to be done at this school often affect my work. I am forced to go for other programmes so it is difficult for me to attend to each and every student." (Mr I.pers.com).
}

The teachers also reported that poor relationship among teachers was an indirect barrier to the effective utilisation of students' learning styles in mathematics lessons. As put forward by two of the mathematics teachers $(13.33 \%)$, the teachers were not working as teams. They were not free to consult each other.

All the mathematics teachers $(100 \%)$ who participated in this study thought that their failure to utilize their knowledge of students' learning styles was partly attributed to overloading. The teachers felt that large classes and too many lessons in a week were overloading them. One of the teachers had the following to say:

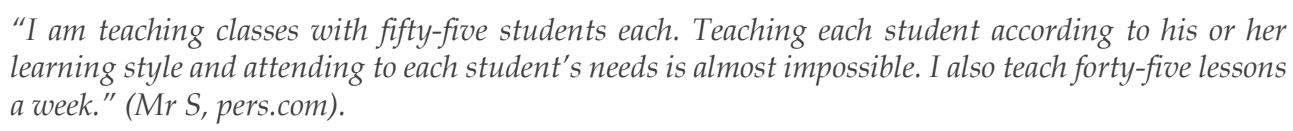

Data obtained through observation confirmed that the mathematics classes were large. One of the classes had sixty-six students.

Negative perception of mathematics as a subject was also viewed as a barrier to the effective use of students' learning styles by the teachers. According to the mathematics teachers, it requires the teacher to put effort in order to assess his or her students and plan instruction that suits the learning styles of the students. However some members of the society including some teachers viewed mathematics as a difficult subject that could only be done by the gifted ones. The perception led to lack of seriousness on the part of the teachers and the students. It also resulted in parents failing to give the much needed moral and financial support to the learning of their children. One of the teachers who shared this view said:

\begin{abstract}
"People view mathematics as a difficult subject. As a result, teachers move with the gifted ones. On the other hand, parents seem to have accepted that only a few students should pass mathematics. The students themselves have accepted failure."(Ms P, pers.com).
\end{abstract}

\section{Curriculum related Barriers}

Some of the barriers obtained from the mathematics teachers were related to the curriculum. Table 6 shows the curriculum related barriers and how they affected the effective use of the teachers' knowledge of students' learning styles in the teaching of mathematics. 
Table 6. Curriculum related barriers and how they affected the teachers' use of students' learning styles in mathematics teaching

\begin{tabular}{ll}
\hline Curriculum related barriers & Effect of the barriers \\
\hline Long syllabi & $\begin{array}{l}\text { Teachers rushed to complete the syllabi within the given time frame without taking care } \\
\text { of the learning styles of their students. }\end{array}$ \\
$\begin{array}{ll}\text { Target on number of written } \\
\text { exercises to be given to students per } \\
\text { week }\end{array}$ & $\begin{array}{l}\text { Teachers became more biased to written work at the expense of practical learning } \\
\text { activities. Students who could learn better through practical exercises did not benefit } \\
\text { much from the exercises given. }\end{array}$ \\
$\begin{array}{ll}\text { Frequent change of regulations, } \\
\text { policies and curriculum }\end{array}$ & $\begin{array}{l}\text { Teachers needed more time to adjust to new policies and new curriculum instead of } \\
\text { paying attention to their students' learning styles. }\end{array}$ \\
\hline Dictated curriculum & $\begin{array}{l}\text { The activities to be done by the students did not match the learning styles of the } \\
\text { students. }\end{array}$ \\
\hline
\end{tabular}

Seven of the teachers $(46.67 \%)$ felt that frequent changes in education regulations, policies and the curriculum contributed towards creating mismatches between teachers' teaching styles and students' learning styles. One of the teachers said:

"While adjustments to the curriculum help schools to keep pace with the fast changing world, it needs to be done properly. If not done well it causes confusion to the learners and the teachers. More time is wasted studying the new syllabi than in assessing students' needs."(Ms P, pers.com).

Data obtained through observation revealed that the teachers had a newly introduced curriculum framework which had been produced by the Ministry of Primary and Secondary Education in Zimbabwe. The mathematics teachers felt that the government through its Ministry of Primary and Secondary Education developed the curriculum framework for schools without consulting them. They felt they were an indispensable stakeholder and had better knowledge of how students learn than the people who developed the framework they were following. According to them, the concepts and activities set in the curriculum did not consider the diverse nature of their students. The activities were not varied enough to challenge students of different learning styles. The teachers complained that activities suitable for students with certain learning styles were omitted. One of the teachers said:

"Some students are good at solving non-routine problems. However, most of the activities stated in the current mathematics syllabi do not give the students an opportunity to practise solving non-routine problems." (Mr H, pers.com).

\section{DISCUSSION}

Differences and similarities were noted in the results obtained in the current study and those obtained from other studies. On the similarities, the mathematics teachers who participated in the current study felt that perceptions on mathematics held by members of the society, especially those held by teachers and students, had a negative effect on the effective utilisation of students' learning styles in mathematics teaching. According to the teachers, the perceptions resulted in mathematics teachers and students exerting little effort to mathematics teaching and learning. Teachers disregarded their students' learning styles. On the other hand, their students accepted their failure and thought they were not good enough to perform better. Almost similar results were obtained by Kaniz (2015) in a study carried out in Bangladesh. In that study, Kaniz found that negative perceptions held by members of the society were a barrier to mathematics teaching.

Weselby (2014) found that shortage of time was a barrier to effective mathematics teaching. Similarly, the current study also found that shortage of time was a serious barrier to effective use of teachers' knowledge of students' learning styles in mathematics teaching. The teachers needed enough time to assess their students, plan instruction that suited the learning styles of their students, deliver lessons and evaluate their teaching methods. However, this was not possible due to time limits caused by poor time tabling. The teachers ended up teaching for the examination and not for understanding. According to the mathematics teachers, time was stolen by other school activities like morning briefings and devotions. Data obtained indicated that the problem was common at church owned schools.

The findings of the current study revealed that shortage of learning resources was a barrier to effective usage of the teachers' knowledge of students' learning styles. Large textbook-students ratios were observed. The shortage of resources made it difficult for the teachers to assist students according to their learning styles. These findings confirmed results obtained in Bangladesh (Kaniz, 2015). Kaniz observed that lack of textbooks and other mathematical instruments was a barrier to effective mathematics teaching in Bangladesh.

The mathematics teachers thought that lack of experience, lack of exposure and lack of in-service courses on the part of the teachers were barriers to the mathematics teachers' use of their knowledge of their students' learning 
styles in mathematics teaching. Similarly to these findings, a study carried out in Kenya by Oisebe (2012) revealed that lack of in-service courses impinged on the teaching of mathematics. In-service courses assist in bringing exposure to teachers. However, for the current study, data obtained on the mathematics teachers' teaching experience indicated that only two of the teachers $(13 \%)$ had less than five years of teaching experience and nine $(60 \%)$ had more than ten years. An analysis of the teachers' lengths of teaching experience showed that what the teachers thought was in contrast to what was on the ground.

The teachers' attitude towards their work affected their use of their knowledge of students' learning styles when teaching mathematics. According to the results obtained from the current study, a teacher maybe well experienced and well trained but if the teacher is not committed to his or her work then no meaningful teaching can take place. The teacher deliberately ignores students' learning styles and teaches in ways that appear to give less work to him or her. This results in the teacher employing rote methods of teaching. In our opinion, the teacher's choice of teaching strategies and teaching aids is determined by the teacher's attitude towards work. A study by Marban and Mulenga (2019) revealed that pre-service mathematics teachers did not use ICT in teaching mathematics because they had a negative attitude towards the use of ICT in teaching. These results confirmed that the teacher's attitude plays a pivotal role in the teacher's choice of teaching strategy.

Lack of commitment on the part of the students was also a barrier to the teachers' use of their knowledge of students' learning styles in mathematics teaching. Similar findings were obtained in a study done in Michigan (Crystal, 2012). Crystal observed that lack of motivation and commitment on the part of the mathematics students in Michigan greatly affected the teaching of mathematics.

Lack of parental support affected teaching of mathematics in Michigan (Crystal, 2012). The results of the current study also revealed that lack of parental support, caused by negative perception on mathematics, was a barrier to the effective use of teacher's knowledge of students' learning styles. The teachers reported that the society viewed mathematics as a difficult subject, hence poorly performing students ended up receiving little support from both their parents and their teachers.

Some differences were noted between the results of the current study and those found in the related literature reviewed. Oisebe (2012) observed that low expectation by the teachers on their students affected mathematics teaching in Kenya. The results of the current study did not show that teachers' expectations on their students affected how the teachers used their knowledge of students' learning styles in mathematics teaching.

In addition to the findings in the reviewed literature, the current study found other barriers. Among them was overloading of teachers. Overloading occurred in two ways. The teachers were overloaded in terms of the number of students per class and in terms of number of lessons they were expected to teach in a week. Overloading made it difficult for the teachers to utilise students' learning styles effectively. Some of the classes had up to sixty-six students. The number made it difficult for the teachers to assess the learning styles of each and every student in the class. The teachers ended up using teacher-centred methods like the lecture method which did not match the learning styles of the students. The data obtained from the study revealed that overloading affected mathematics teachers at government owned schools.

It was observed that the mathematics teachers had long syllabi to cover within stipulated time and targets to meet in terms of number of written exercises given to students per week. These added on pressure to the teachers resulting in them failing to plan for instruction that suited their students. Teachers gave written exercises even in cases where practical exercises would be suitable.

Other barriers reported by the mathematics teachers were lack of subject content knowledge by the teachers and failure by the mathematics teachers to integrate mathematics with other learning areas. The teachers thought that lack of subject content knowledge led to over reliance on textbooks which resulted in mismatches between teaching strategies and learning styles of the students. In our view, mathematics cannot be taught in isolation. Understanding maths learners and interpersonal maths learners enjoy applying mathematics skills to real life problems (Perini, Silver \& Strong, 2000). Mathematics teachers should take advantage of the skills learnt by their students in other learning areas. It assists students to appreciate the fact that mathematics is a tool used in solving real life problems.

The study also revealed that some of the barriers were related to negative behaviours by students. These included lack of practice, negative self-esteem and negative attitude towards teachers. According to Kaniz (2015) such behaviours by students are caused by too much punishment imposed on students by teachers for failing to perform given tasks. However, the negative behaviours by students made it difficult for the teachers to effectively utilise the students' learning styles to the best advantage of the students.

The teachers thought that unfavourable policies were also barriers to the effective utilisation of students' learning styles in mathematics teaching. They reported that the government sometimes dictate curriculum to be followed in schools. It resulted in teachers failing to match their teaching styles and their students' learning styles. 
According to the teachers, the dictated curriculum did not contain activities that were varied enough to cater for students of different learning styles.

\section{RECOMMENDATIONS}

Based on the results of the study, the researchers recommend that mathematics teachers be in-serviced on how to effectively utilise their students' learning styles when teaching mathematics. The in-service exercises should focus on developing teachers' skills on matching their teaching styles and their students' learning styles, integrating mathematics learning with other learning areas, utilising locally available resources and keeping students motivated. Integrating mathematics with other learning areas is a skill that every mathematics teacher should possess. It assists teachers to cater for understanding maths learners and interpersonal maths learners. The teachers should utilise skills obtained by their students in other learning areas to develop skills in solving problems in mathematics. The following activities give examples of how a mathematics teacher can integrate Mathematics with other learning areas:

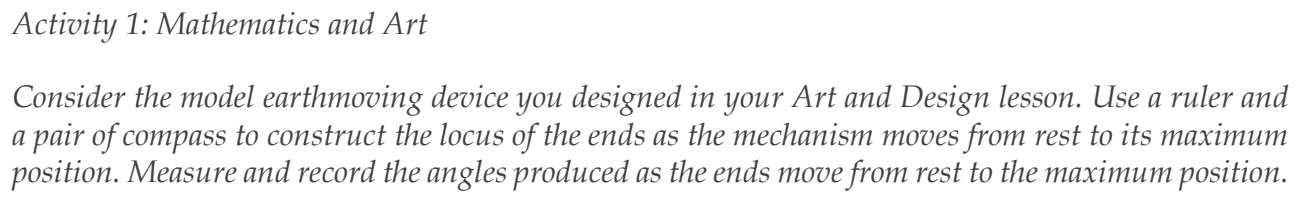

Figure 3 shows a photograph of a model of an earth moving device produced by one of the students during an Art and Design lesson.

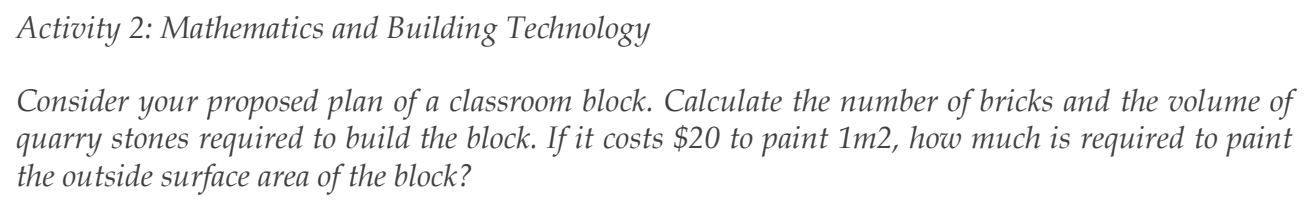

In order to reduce the effects of student related barriers like absenteeism, indiscipline, negative attitude towards mathematics learning and lack of concentration by students, the mathematics teachers should vary learning environments. Restricting mathematics learning to the classroom does not challenge students' learning styles. Learning excursions give students an opportunity to apply mathematical concepts to real life situations. It makes students appreciate that mathematics is a problem solving tool. The excursions reduce the monotony that students normally associate with mathematics learning. An example of how a teacher can make use of an excursion is when he or she teaches volume of shapes. The teacher instructs students to identify shapes in the environment like lunch boxes, cereal boxes, buildings, rubbish bins and others. The students measure the dimensions of the shapes. They use the dimensions to calculate volume of the shapes. The results can be represented in table form. Such an exercise helps the teacher to take care of students of different learning styles. For instance, Mastery maths learners get an opportunity to apply formulae used in calculating volume. Understanding maths learners will enjoy studying how the formulae work in calculating volume of real objects. Self-expressive maths learners explore alternative ways of calculating volume of the objects. Interpersonal maths learners work in groups to measure the dimensions and calculate the volume of the shapes.

It is also recommended that teachers give their students activities drawn from real life situations. It assists in reducing the effects of student related barriers like lack of concentration. The activities should be varied in ways that cater for varying students' learning styles. The following is an example of such activities:

Draw a cylindrical tank with a base diameter of $20 \mathrm{~m}$ and a height of $8 \mathrm{~m}$. Calculate the volume of the tank(hint; volume=base area $x$ height). If it takes 5 minutes to fill $1 \mathrm{~m} 3$ of the tank with water, how long does it take to fill up the tank with water? Design a suitable roof for the tank and calculate the volume of the roof.

The given example allows students to compute, apply mathematical concepts to a real life situation, apply given formula and make designs. All the four classes of learners as stipulated by Perini, Silver and Strong (2000) are taken care of with such an instruction; hence they are all kept active.

The researchers also recommend that mathematics teachers adopt collaborative teaching method. Collaborative teaching entails that the teachers assist each other in planning, teaching and evaluating lessons. If the mathematics teachers work together, it helps in overcoming teacher related barriers like lack of subject content knowledge, lack of exposure and failure to integrate mathematics with other learning areas. The method assists teachers to develop skills that are useful in dealing with students of varying learning styles. The mathematics teachers need to meet 
regularly at various levels for them to discuss and staff develop each other. Mathematics teachers' associations should be formed. The members of such associations should be drawn from grassroots level right up to the highest level in the school system. The associations work as mechanisms for exchanging ideas on mathematics teaching.

Mathematics clubs, mathematics camps and activities of regional mathematics associations can assist in improving the perceptions held by students and the society on mathematics as a learning area. When the perceptions improve, it makes it easy for the teachers to effectively utilize their knowledge of students' learning styles. The researchers therefore recommend that mathematics clubs and camps be introduced in schools.

Teachers are important stakeholders in the school system. It is of paramount importance that mathematics teachers take part in the development of the school curriculum. Teachers assist in ensuring that the curriculum benefit students of varying learning styles. They help in making sure that the content can be covered within the required period. The mathematics syllabus need not be too academic as it may fail to meet the needs, demands and interests of students of varying learning styles. It needs to include functional mathematics concepts that help students to link mathematics learning and societal problem solving.

Responsible authorities at schools should provide materials that enable mathematics teachers to utilise their knowledge of students' learning styles. Societies are fast becoming information communication technology (ICT) compliant, hence there is a need for schools to keep pace with the demands of the modern students. Providing teaching resources motivates the teachers. It improves the teachers' attitude towards work. On the other hand, the teachers need to be resourceful. The teachers should utilise the resources obtainable in their local environment in order to suit the learning styles of their students. For instance, cell phones can be used for mathematical games in place of desktops. Old cereal boxes of different sizes can be used as teaching aids to teach similarity and congruency of shapes. Bottles can be graduated and can be used as measuring cylinders.

\section{ACKNOWLEDGEMENTS}

The researchers thank all the mathematics teachers who participated in the study. The data obtained from them made the research a success. The researchers also thank the experts that assisted in structuring the interview guide and observation checklist that were used to obtain data from the mathematics teachers.

\section{REFERENCES}

Allan, S. D., \& Tomlinson, C. A. (2000). Leadership for differentiated schools and classrooms. Alexandria: ASCD.

Bengtsson, M. (2016). How to plan and perform a qualitative study using content analysis. NursingPlus Open, 2, 814. https:/ / doi.org/10.1016/j.npls.2016.01.001

Carlson, A. M. (2018). What is differentiated instruction? Examples, definition and activities. Retrieved on 17 April 2019 from https://study.com/academy/lesson/what-is-differentiated-instruction-examples-definitionactivities.html

Crystal, S. (2012). A comparison of barriers to teaching and learning of Mathematics and Science across a three year study of misconceptions management professional development. Michigan: College of Education and Human Development.

Haar, J., Hall, G., Schoepp, P., \& Smith, D. (2002). How teachers teach to students with different learning styles. Clearing House: A journal of educational strategies, issues and ideas, 75(3), 142-145. https:/ / doi.org/10.1080/00098650209599254

Honey, P., \& Mumford, A. (1982). Manual of Learning Styles. London: P Honey.

Kaniz, F. D. (2015). Barriers in teaching learning process of mathematics at secondary level: A quest of quality improvement. American Journal of Educational studies, 3(7), 822-831.

Kolb, D. (1984). Experiential learning: Experience as the source of learning and development. Engle wood Cliffs: PrenticeHall, Inc.

Mangwende, E., \& Maharaj, A.(2018). Secondary school mathematics teachers' use students' learning styles when teaching functions: A case of Zimbabwean schools. EURASIA Journal of Mathematics, Science and Technology, 14(7), 3225-3233. https:/ / doi.org/10.29333/ ejmste/91679

Marban, J. M., \& Mulenga, E. M. (2019). Pre-service Primary Teachers' Teaching Styles and Attitudes towards the Use of Technology in Mathematics Classrooms. International Electronic Journal of Mathematics Education, 14(2), 253-263. https://doi.org/10.29333/iejme/5649

McLeod, S. A. (2017). Kolb-learning styles. Retrieved on 17 April 2018 from http:/ / www.simplypsychology.org/learning-kolb.html 
Nziramasanga, C. T., Malaba, G., Kachingwe, S. L., \& Gerbecks, H. (1999). Report of the presidential commission of inquiry into education and training. Harare: Nziramasanga Commission of Inquiry.

Oisebe, M. V. (2012). Barriers to the teaching-learning of mathematics in secondary schools in Masaba South District, Kisii County, Kenya. Mabasa: MST- Department of Educational Management Policy and Curriculum Studies.

Patel, K. L., \& Singh, S. (2014). Matching and Mismatching of learning styles and teaching styles: A conceptual perspective. Shaikshik Parisamvad (An International Journal of Education), 4, 20-26.

Peacock, M. (2001). Match or mismatch: Learning styles and teaching styles in EFL. International Journal of Applied Linguistics, 11(1), 1-20. https:/ / doi.org/10.1111/1473-4192.00001

Perini, M. J., Silver, H. F., \& Strong, R. W. (1997). Integrating Learning Styles and Multiple Intelligences. Educational leadership, 55(1), 22-27.

Perini, M. J., Silver, H. F., \& Strong, R. W. (2000). So each may learn: Integrating learning styles and multiple intelligences. Alexandria: Association for Supervision and Curriculum Development.

Reid, J. M. (1987). The learning style preferences of ESL Students. TESOL Quarterly, 21(1), 87-111. https:/ / doi.org/10.2307/3586356

Tomlinson, C. A. (2001). How to differentiate instruction in mixed-ability classrooms. Alexandria: Association for Supervision and Curriculum Development.

Weselby, C. (2014). What is differentiated instruction? Examples of how to differentiate instruction in the classroom. Oregon: Concordia University.

Zaidah, Z. (2007). Case study as research method. Jurnal Kemanusiaan, 9, 1-6.

Zeeb, M. S. (2004). Improving student success through matching learning and teaching styles. Phoenix: University of Phoenix.

\section{http://www.ejmste.com}

